\title{
Soil water during the drought of 2012 as affected by rye cover crops in fields in lowa and Indiana
}

\author{
A.L. Daigh, M.J. Helmers, E. Kladivko, X. Zhou, R. Goeken, J. Cavdini, D. Barker, and J. Sawyer
}

\begin{abstract}
The drought of 2012 provides a unique opportunity to evaluate the effects of cover crop on soil moisture under relatively extreme conditions. The objective of this study was to quantify potential differences in soil moisture due to the presence of a rye (Secale cerale L.) cover crop in a corn (Zea mays L.)-soybean (Glycine max L.) rotation at various locations in the Midwestern United States during the drought of 2012. Soil volumetric water content $(\theta)$ and soil water storage (SWS) were monitored at three sites in Iowa and Indiana. Daily measurements of soil $\theta$ were taken at $10,20,40$, and $60 \mathrm{~cm}(3.9,7.9,15.7$, and $23.6 \mathrm{in})$ soil depths, and SWS was estimated to an $80 \mathrm{~cm}$ (31.5 in) depth. Soil water during the drought of 2012 was affected by a rye cover crop in comparison to without a rye cover crop for one (i.e., located in Iowa) of the three sites monitored. At the Iowa site, soil $\theta$ was on average 0.041 and $0.033 \mathrm{~cm}^{3} \mathrm{~cm}^{-3}\left(0.041\right.$ and $\left.0.033 \mathrm{in}^{3} \mathrm{in}^{-3}\right)$ greater at the 10 and $20 \mathrm{~cm}(3.9$ and $7.8 \mathrm{in})$ depths, respectively, following termination of a rye cover crop than crops without a rye cover crop. Thus, during the 2012 drought, the use of a rye cover crop as compared to without a rye cover crop in a corn-soybean rotation did not significantly lower soil water conditions. The use of a cover crop either had no impact or significantly increased soil water conservation.
\end{abstract}

Key words: cover crops-drought—-soil water

\begin{abstract}
The year of 2012 was one of the driest years on record since the $1950 \mathrm{~s}$, and it is consistent with climate predictions of increased weather variability for the coming decades (Schiermeier 2013; NOAA NCDC 2012; Seneviratne 2012; Gilbert 2012; Easterling and Karl 2001). During times of drought, soil management strategies that impact soil moisture may either exacerbate or add resistance and/or resiliency against the effects of drought on cash crops (Hatfield 2011; Sadras and Angus 2006; Hatfield at el. 2001; Wagger and Mengel 1988; Cambell et al. 1984). The Climate and Corn-based Cropping Systems Coordinated Agricultural Project (CSCAP) is a transdisciplinary partnership among 11 institutions across the midwestern United States which aims to assess the impact of land management decisions and climate variability on corn (Zea mays L.) systems resiliency and sustainability across the midwestern United States. Therefore, CSCAP project sites under cover crop management in corn-soybean (Glycine max L.) rotation allowed for investiga-
\end{abstract}

tion of the effects of rye (Secale cerale L.) cover crops on soil moisture during the drought of 2012 and thus give insight on potential benefits and/or drawbacks of cover crops during future climate variation.

In general, the potential effects of winter cover crops on soil water content $(\theta)$ and soil water storage (SWS) are well known, but contradicting results are reported in the literature as to their effects on the following cash crops (Kaspar and Singer 2011; Miguez and Bollero 2006; Ball Coelho et al. 2005; Hansen et al. 2000; Johnson et al. 1998; Raimbault et al. 1990). Cover crops grown during what would otherwise be fallow periods of corn-soybean rotations are well known for reducing drainage volumes, nitrate $\left(\mathrm{NO}_{3}-\mathrm{N}\right)$ leaching, and soil erosion; suppressing weeds, plant pathogens, and nematodes; increasing soil organic matter; and improving soil physical properties and biological activity (Daigh et al. 2014; Qi and Helmers 2010; Reeleder et al. 2006; Strock et al. 2004; Kladivko et al. 2004; Kaspar et al. 2001; Inderjit and
Keating 1999; Dapaah and Vyn 1998; Unger and Vigil 1998; Wander et al. 1994; Patrick et al. 1957). However, a growing cover crop is also transpiring water. This may significantly reduce soil $\theta$ and SWS, leaving potentially low antecedent soil water availability to emerging and young cash crop in years when water limiting stress may be high, such as the 2012 drought (Ewing et al. 1991; Campbell et al. 1984). In contrast, standing or laying vegetation above the soil surface, whether living or dead, raises a field's atmospheric boundary layer, reduces wind speeds at the soil surface, and lowers soil short wave radiation absorption, all resulting in potentially lower soil evaporative losses (McMaster et al. 2000; Sauer et al. 1996a, 1996b; Horton et al. 1996; Horton 1989; Wagger and Mengel 1988). These phenomena are collectively well known as the mulch effect. In addition, the presence of plant tissue surface area above the soil surface increases the potential for dew formation and potential stem flow to the soil surface if enough water vapor is condensed on plant tissues. The mulch effect, potential enhancement of dew formation, and in the long term any increases in soil water holding capacity due to increases in soil organic matter content, could potentially increase antecedent soil water availability to emerging and young cash crop (Mulumba and Lal 2008; Clark et al. 1997b; Waggner and Mengel 1988; Moschler et al. 1967). Therefore, given the numerous and potentially opposing effects cover crops may have on soil moisture and corresponding effects on the following cash crop, our objective was to quantify potential differences in soil moisture

Aaron Lee Daigh is an assistant professor in the Department of Soil Science at North Dakota State University in Fargo, North Dakota. Matthew J. Helmers is an associate professor in the Department of Agricultural and Biosystems Engineering at lowa State University in Ames, lowa. Eileen Kladivko is a professor in the Department of Agronomy at Purdue University in West Lafayette, Indiana. Xiaobo Zhou is a scientist at Monsanto in St. Louis, Missouri. Ryan Goeken is a graduate student in the Department of Agricultural and Biosystems Engineering at lowa State University in Ames, lowa. Jason Cavadini is a graduate student in the Department of Agronomy at Purdue University in West Lafayette, Indiana. Daniel Barker is an assistant scientist in the Agronomy Department at lowa State University in Ames, lowa. John Sawyer is a professor in the Agronomy Department at lowa State University in Ames, lowa. 
due to the presence of a rye cover crop in a corn-soybean rotation at various locations in the midwestern United States during the drought of 2012. Utilizing data from 2012 allows for unique opportunity to evaluate the effects of cover crop on soil moisture under relatively extreme conditions.

\section{Methods and Materials}

Site Descriptions. Soil $\theta$ and SWS were monitored at the Agricultural Drainage Water

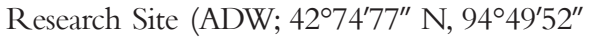
W) and the Iowa State University Agronomy and Agricultural Engineering Research Farm (ISUAG; $42^{\circ} 00^{\prime} 94^{\prime \prime} \mathrm{N}, 93^{\circ} 78^{\prime} 06^{\prime \prime} \mathrm{W}$ ) in Iowa during 2012 and at the Southeast Purdue Agricultural Center (SEPAC; 39 $02^{\prime} 85^{\prime \prime} \mathrm{N}$, $\left.85^{\circ} 54^{\prime} 00^{\prime \prime} \mathrm{W}\right)$ in Indiana during 2011 to 2012. Plot sizes were $15 \times 38 \mathrm{~m}(49.2 \times 124.7 \mathrm{ft})$, $15 \times 6 \mathrm{~m}(49.2 \times 19.7 \mathrm{ft})$, and $18 \times 360 \mathrm{~m}$ $(59 \times 1181.1 \mathrm{ft})$ at ADW, ISUAG, and SEPAC, respectively (figure 1). Among the sites, soils ranged from poorly drained glacial till Mollisols to well drained loess Alfisols (table 1$)$. Mean annual temperatures are $8.1^{\circ} \mathrm{C}\left(46.5^{\circ} \mathrm{F}\right)$, $9.5^{\circ} \mathrm{C}\left(49.1^{\circ} \mathrm{F}\right)$, and $12.6^{\circ} \mathrm{C}\left(54.6^{\circ} \mathrm{F}\right)$ at ADW, ISUAG, and SEPAC, respectively (NOAA 2013; NOAA NCDC 2013). Mean annual precipitations are 84.7, 90.7, and $118.6 \mathrm{~cm}$ $(33.3,35.7$, and 46.7 in) at ADW, ISUAG, and SEPAC, respectively (NOAA 2013; NOAA NCDC 2013). The three research sites were

\section{Figure 1}

Map and schematic of the Agricultural Drainage Research Site (ADW), lowa State University Agronomy and Agricultural Engineering Farm (ISUAG), and Southeast Purdue Agricultural Center (SEPAC) sites.

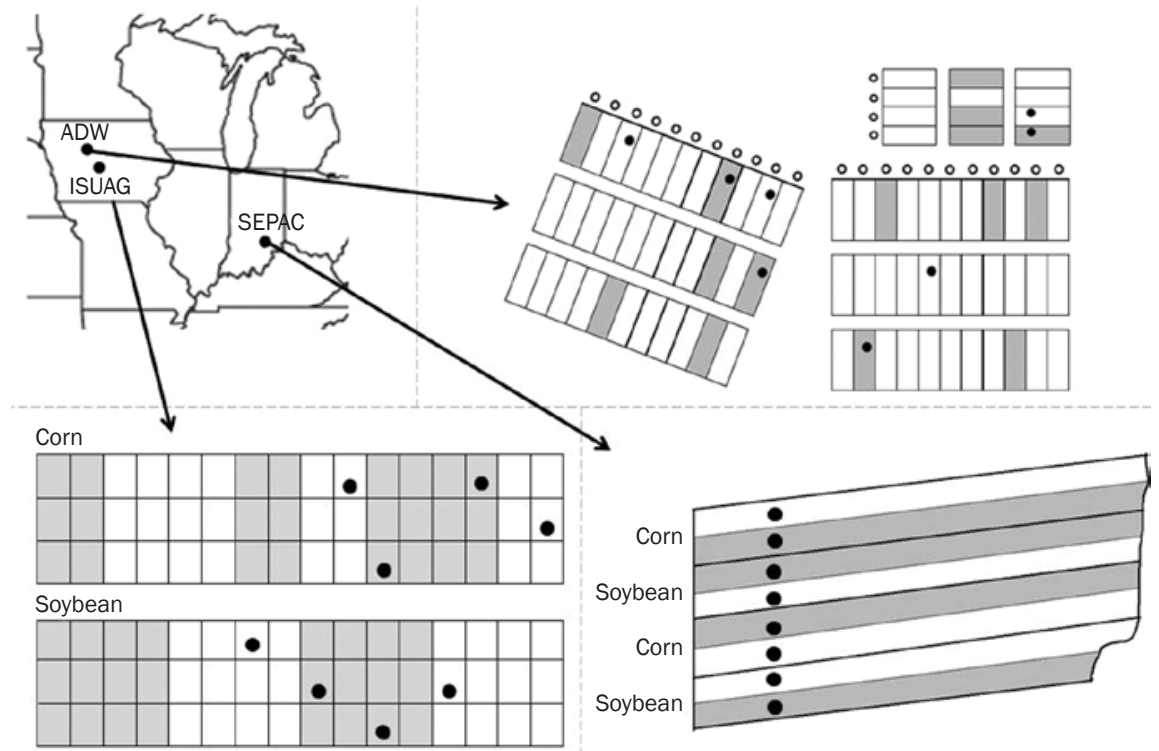

\section{Legend}

- Sensor $\square$ Rye cover crop $\square$ No cover crop

used to capture a range of climatic conditions that might reflect different amounts of winter rye cover crop biomass production and potentially subsequent impacts on soil moisture.
Treatments, Experimental Design, and Field Management. At each research site, four crop treatments were selected. These treatments consisted of corn following rye

\section{Table 1}

General site characteristics at Agricultural Drainage Research Site (ADW), lowa State University Agronomy and Agricultural Engineering Farm (ISUAG), and Southeast Purdue Agricultural Center (SEPAC) sites.

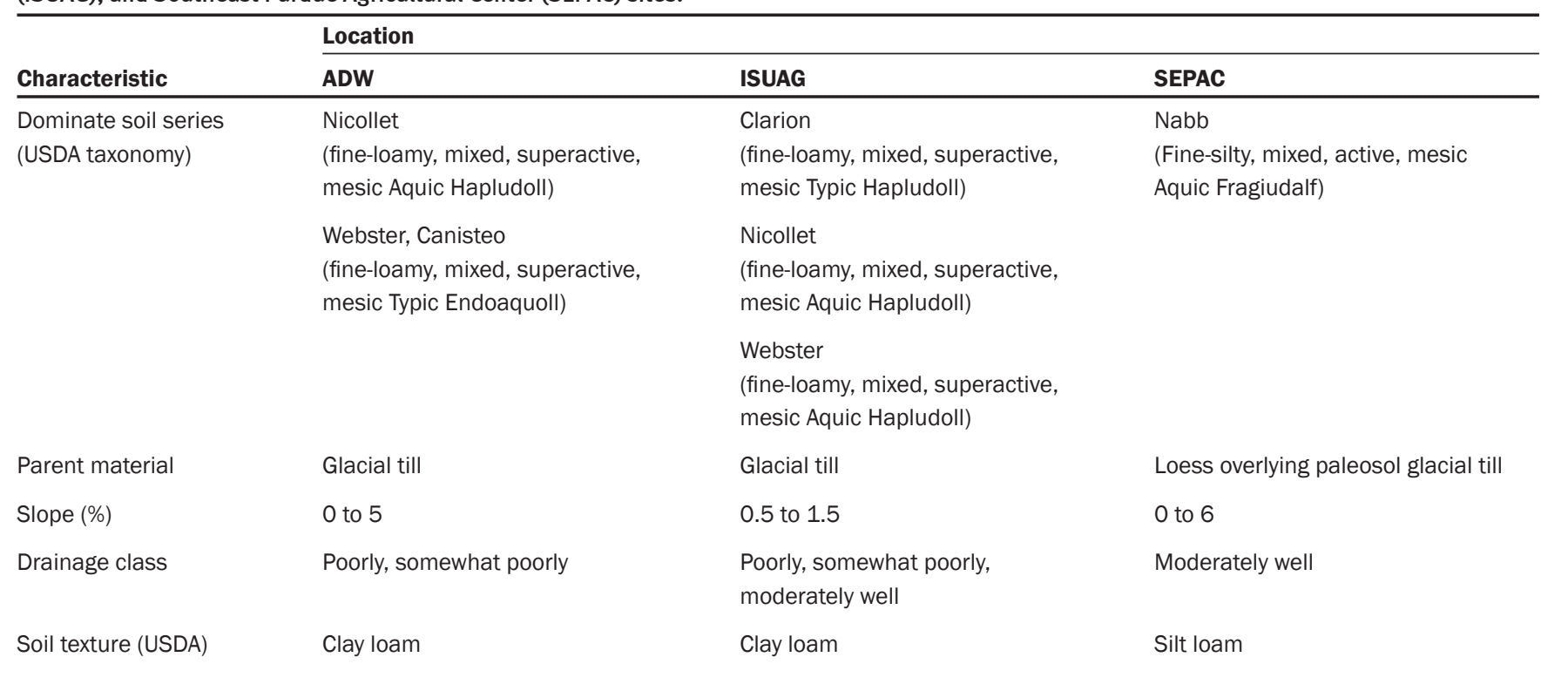


$(\mathrm{rC})$, corn without rye (Cs), soybean following rye $(\mathrm{rS})$, and soybean without rye $(\mathrm{cS})$. In each plot, corn and soybean were planted in rotation, and so the main crop in each treatment refers to the crop planted following rye growth and termination in the spring of 2012. All three sites have a history of corn and soybean rotations dating back to at least the early 1900s. Rye cover crop treatments were established in 2008, 2010, and 2011 at ISUAG, ADW, and SEPAC, respectively.

To precisely estimate SWS with depth in the soil profile, a great quantity of sensors $(n=96)$ and data logger equipment ( $n$ $=24$ ) were required (see following section on soil moisture measurements), limiting the number of treatment replications (i.e., two replications) possible for each of the research sites. By limiting the number of treatment replication, an unknown degree of precision can be lost for estimating treatment means and the experimental error variance, thereby also limiting the ability to detect differences among treatments. However, the great quantity of repeated measurements obtained in each replication (see following section on statistical analyses) would have increased the precision of treatment means and the experimental error variance estimated across time. In order to precisely quantify soil $\theta$ and SWS with depth and across time, crop treatments were replicated twice in randomized complete block designs for each research site.

For the ADW and ISUAG sites, two time periods of interest were defined; period 1 is March 1, 2012, to the planting of the cash crop and period 2 is emergence of cash crop to July 10, 2012. Corn and soybean were planted on May 10 and May 16, respectively, at ADW. Corn and soybean were planted on April 26 and May 11, respectively, at ISUAG. The ISUAG and ADW sites have long histories of corn and soybean rotations throughout the 1900s. The initiation of rye cover crops treatments at ISUAG and ADW were 4 and 2 annual growing seasons, respectively, prior to the observation periods used in this study in 2012. Since the initiation of the rye cover crop treatments at ISUAG and ADW, the same variety and seeding rates were used and similar above- ground annual biomass production was observed each year. Therefore, any differences in soil moisture prior to the observation periods in 2012 are assumed to be due to and representative of the corn-soybean rotation with or without a winter rye cover crop.
Four time periods of interest were defined at SEPAC due to the fall of 2011 being the first year initiating the rye cover crop treatments. Period -2 is prior to planting of rye from July 14 to August 20, 2011; period -1 is when rye was dormant from January 1 to February 12 in 2012; period 1 is March 1 to the planting of the cash crop in 2012; and period 2 is emergence of cash crop to July 20, 2012. Thus, if any statistical differences among treatments were observed in periods -2 (i.e., prior to the initiation of the rye cover crop) that also persisted into any later observation period would likely be associated with the preexisting site conditions and not due to the rye cover crop treatment. Corn and soybean were planted on April 24 at SEPAC.

Rye was drilled in at a rate of 100,63 , and $78 \mathrm{~kg} \mathrm{ha}^{-1}\left(89.3,56.3\right.$, and $\left.69.6 \mathrm{lb} \mathrm{ac}^{-1}\right)$ at ADW, ISUAG, and SEPAC, respectively, between October 3 and October 12, 2011. Rye was allowed to grow during the winter and spring months and was terminated via glyphosate application (i.e., 1.4, 1, and $1.2 \mathrm{lb}$ active ingredient $\mathrm{ac}^{-1}$ at ISUAG, ADW, and SEPAC, respectively) on April 12 for $\mathrm{rC}$ and May 9 for $\mathrm{rS}$ at ADW, on April 6 for $\mathrm{rC}$ and May 11 for $\mathrm{rS}$ at ISUAG, and on March 26 for both $\mathrm{rC}$ and $\mathrm{rS}$ at SEPAC in 2012.

At the ADW site, subsurface drainage lines were installed in 1989 at a depth of 1.06 $\mathrm{m}(3.5 \mathrm{ft})$ with a $7.6 \mathrm{~m}$ (24.9 ft) spacing between drainage lines (Lawlor et al. 2008). However, at ISUAG, the amount and placement of subsurface drains are unknown as the site was previously used as a bulk farmed agricultural field. Subsurface drainage was not used at SEPAC.

Soil Moisture and Biomass Measurements. Volumetric soil water content was monitored at one hour or finer time intervals using a Decagon Em50 Data Logger with Decagon 5TE and 5TM soil moisture sensors installed at $10,20,40$, and $60 \mathrm{~cm}(3.9,7.9,15.7$, and 23.6 in) depths in each plot on all sites (Decagon Devices, Inc., Pullman, Washington). Sensors were installed at the quarter-plant-row position for all plots and midway between tile drains at the ADW site. A hand auger was used to excavate soil, forming a vertical hole where soil sensors were inserted into undisturbed soil of the vertical hole wall and parallel to the soil surface. Then, the vertical hole was backfilled with soil and densely packed by hand, with the sensor electrical cords placed along the opposite soil wall as the soil sensors. Soil sensors were installed two years prior at ISUAG and ADW and seven months prior at SEPAC to the observation periods in this study. Thus, any alteration to soil water movement resulting from sensor installation is assumed to be negligible. Soil water storage was estimated by sectioning the soil into 0 to $15 \mathrm{~cm}(0$ to 5.9 in), 15 to $30 \mathrm{~cm}$ (5.9 to $11.8 \mathrm{in}$ ), 30 to 50 $\mathrm{cm}$ (11.8 to $19.7 \mathrm{in})$, and 50 to $80 \mathrm{~cm}$ (19.7 to $31.5 \mathrm{in}$ ) depth intervals and assuming the corresponding soil $\theta$ measurement within that depth interval represented the entire depth interval. Soil $\theta$ was multiplied by the height of the soil depth interval to get centimeters of water per square $\mathrm{cm}$ of soil. Then, total soil profile water storage was determined by summing together the centimeters of water of all four soil depth intervals to an $80 \mathrm{~cm}$ (31.5 in) soil depth for each measurement time period. The thicknesses of the two deeper soil depth intervals are greater than those near the surface. The thinner soil depth intervals near the soil surface allow for greater precision when estimating SWS since vertical stratification of soil moisture is expected to occur more frequently at shallower depths than that of deeper depths for soils without hydraulicly limiting layers. In contrast, if significant vertical stratification of soil moisture does occur in the subsoil, the precision of the estimated SWS will be unknown. Soils classified at ISUAG and ADW in Iowa do not have such hydraulically limiting layers in the subsoil. However, the soils classified at SEPAC in Indiana have fragic properties in the subsoil and may be prone to unobserved levels of vertical stratification in soil moisture within the deepest soil depth interval. Therefore, daily values of both soil $\theta$ at soil depths of 10 and $20 \mathrm{~cm}$ (3.9 and $7.9 \mathrm{in}$ ) and SWS to $80 \mathrm{~cm}$ (31.5 in) soil depth are reported and used in all statistical analyses.

Total aboveground living biomass was sampled for all plots on the day of rye termination. In each plot, four to six randomly chosen $0.3 \times 0.3 \mathrm{~m}(1 \times 1 \mathrm{ft})$ areas were hand clipped for all aboveground living biomass, then the biomass was dried at $65^{\circ} \mathrm{C}$ $\left(149^{\circ} \mathrm{F}\right)$ for 72 hours and then weighed. Total aboveground living biomass values are reported on a dry-weight basis.

Statistical Analyses. To determine differences in soil $\theta$ and SWS in the corn-soybean rotation with and without a winter rye cover crop, soil $\theta$ and SWS was analyzed using a mixed model repeated measure analysis of variance (RPM ANOVA), with day of year as the repeated factor. Statistical analyses were 
performed separately for the three field locations, two depths, soil profile water storage, and two time periods (four time periods for SEPAC). Covariate structure selection was based on the smallest value of both Akaike Information Criterion with correction for finite samples and Baysean Information Criterion fit statistics. An Auto Regressive Moving Average $(1,1)$ covariate structure was used for all analyses. All statistics were performed in Statistical Analysis System (version 9.3, SAS Institute, Inc, Cary, North Carolina) and means were separated at the 0.10 level.

\section{Results and Discussion}

At all sites, the observed monthly cumulative precipitation was generally similar to the 30-year monthly mean during the beginning portion of observation period 1, but then diverged into drought conditions toward the later portion of observation period 1 and all of period 2 (figure 2). Since at least 1986, approximately 1 year out of every 3 years display a similar trend in cumulative precipitation, between March 1 and July 12, diverging from the 30-year mean cumulative precipitation in late April or early May, similar to that observed in 2012, or earlier in March (figure 3). Thus, any conclusions made from this study are expected to be representative of such years with drought or drought-like periods in spring and early summer. At SEPAC, drought conditions were evident during period -2 but not during period -1 (figure 2). Precipitation deviated from the 30-year monthly mean the greatest at ISUAG of the three sites, which occurred primarily during period 2 (figure 2 ).

The mean, minimum, and maximum soil $\theta$ were $0.260,0.080$, and $0.440 \mathrm{~cm}^{3} \mathrm{~cm}^{-3}$ $\left(0.260,0.080,0.440 \mathrm{in}^{3} \mathrm{in}^{-3}\right)$ whereas the standard deviation and coefficient of variation were $0.050 \mathrm{~cm}^{3} \mathrm{~cm}^{-3}\left(0.050 \mathrm{in}^{3} \mathrm{in}^{-3}\right)$ and $19 \%$ across all treatments, depth intervals, and dates of observation. The mean, minimum, and maximum SWS were 19.4, 12.6, and $27 \mathrm{~cm}$ (7.6, 5, and $10.6 \mathrm{in})$ whereas the standard deviation and coefficient of variation were $2.7 \mathrm{~cm}$ (1.1 in) and 14\% across all treatments, depth intervals, and dates of observation. These values fall within the range of soil moisture conditions suitable for plant growth in clay loam and silt loam soils (i.e., above plant wilting point of $\sim 0.150 \mathrm{~cm}^{3}$ $\mathrm{cm}^{-3}\left[0.150 \mathrm{in}^{3} \mathrm{in}^{-3}\right]$ soil $\theta$ ) (Or et al. 2012) with exception of when soil $\theta$ fell to as low as $0.080 \mathrm{~cm}^{3} \mathrm{~cm}^{-3}\left(0.080 \mathrm{in}^{3} \mathrm{in}^{-3}\right)$. However,

\section{Figure 2}

Observed and 30-year monthly mean precipitation for all observation periods across the Agricultural Drainage Research Site (ADW), lowa State University Agronomy and Agricultural Engineering Farm (ISUAG), and Southeast Purdue Agricultural Center (SEPAC) sites. Period -2 was prior to planting of rye from July 14 to August 20 in 2011 (SEPAC only), period -1 was when rye was dormant from January 1 to February 12 in 2012 (SEPAC only), period 1 represents the time period prior to planting of the cash crop, and period 2 represents time after rye termination and emergence of the cash crop.

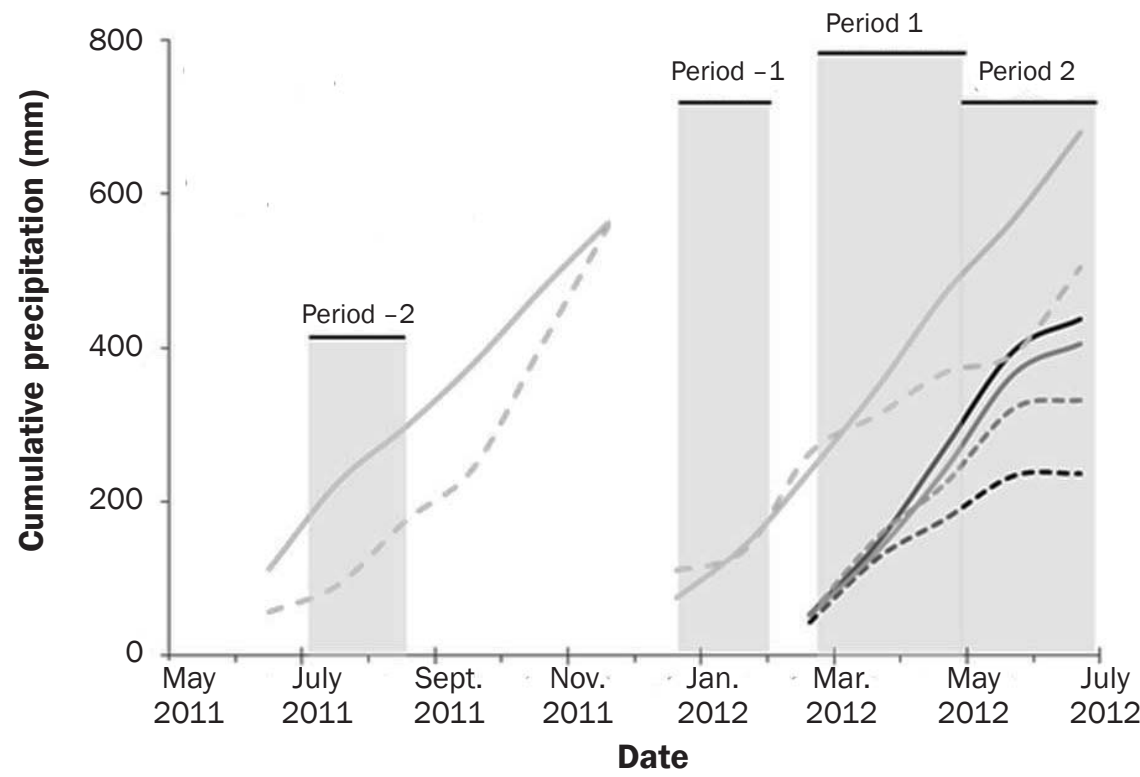

Legend
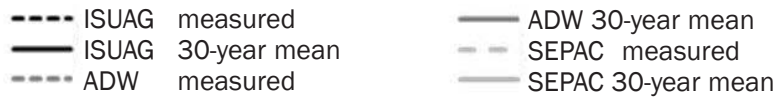

this was only observed during period -2 at SEPAC in depth 1 of block 2 for the previous production corn crop prior to the initiation of the rye cover crop treatments. The lowest SWS observed was $12.6 \mathrm{~cm}$ (5 in) and would equate to an average soil profile $\theta$ of $0.158 \mathrm{~cm}^{3} \mathrm{~cm}^{-3}\left(0.158 \mathrm{in}^{3} \mathrm{in}^{-3}\right)$ (figure 4). This highlights that there were times during the observation period when the entire $80 \mathrm{~cm}$ (31.5 in) profile approached the plant wilting point. As expected, the temporal variations of soil moisture by date contributed the greatest $(>72 \%)$ of the total observed variability for all sites, soil depths, and observation periods (tables 2 and 3). In contrast, crop type, whether a rye cover crop was present or not, or a crop by rye interaction effect contributed between $<0.1 \%$ and $12.2 \%$ of the total observed variability among all sites, soil depths, and observation periods (tables 2 and 3). Although presence of a rye cover crop and type of cash crop contribute relatively little to soil moisture compared to that of frequency of precipitation and atmospheric vapor pressure deficit, soil moisture conditions that restrict seasonal evapotranspiration in corn as little as $4.2 \mathrm{~cm}$ (1.7 in) can reduce grain yields by $25 \%$ to $50 \%$ if water-limiting stress occurs before or at anthesis (even if only for 1 to 2 days) when total water use is greatest (Irmak et al. 2000; French and Schultz 1984; Fulton 1970; Denmead and Shaw 1960).

Rye cover crop treatments did not significantly affect soil $\theta$ and SWS at ADW for either time periods observed in 2012. This was somewhat expected due to the low production of aboveground living biomass generated by the rye cover crop treatments (i.e., 162 and $324 \mathrm{~kg} \mathrm{ha}^{-1}$ [145 and $289 \mathrm{lb}$ $\mathrm{ac}^{-1}$ ] in $\mathrm{rC}$ and $\mathrm{rS}$, respectively; table 4). The relatively low production of aboveground rye cover crop biomass at ADW has also been observed in previous years. This is attributed 


\section{Figure 3}

Thirty-year mean cumulative precipitation from March 1 through July 12 and cumulative precipitation for years that produced $\leq 66 \%$ of the 30 -year mean cumulative precipitation between 1986 and 2012 at the lowa State University Agronomy and Agricultural Engineering Research Farm (ISUAG). For each year, deviation of cumulative precipitation from the 30-year mean cumulative precipitation is identified with a circle along the 30 -year mean cumulative precipitation line.

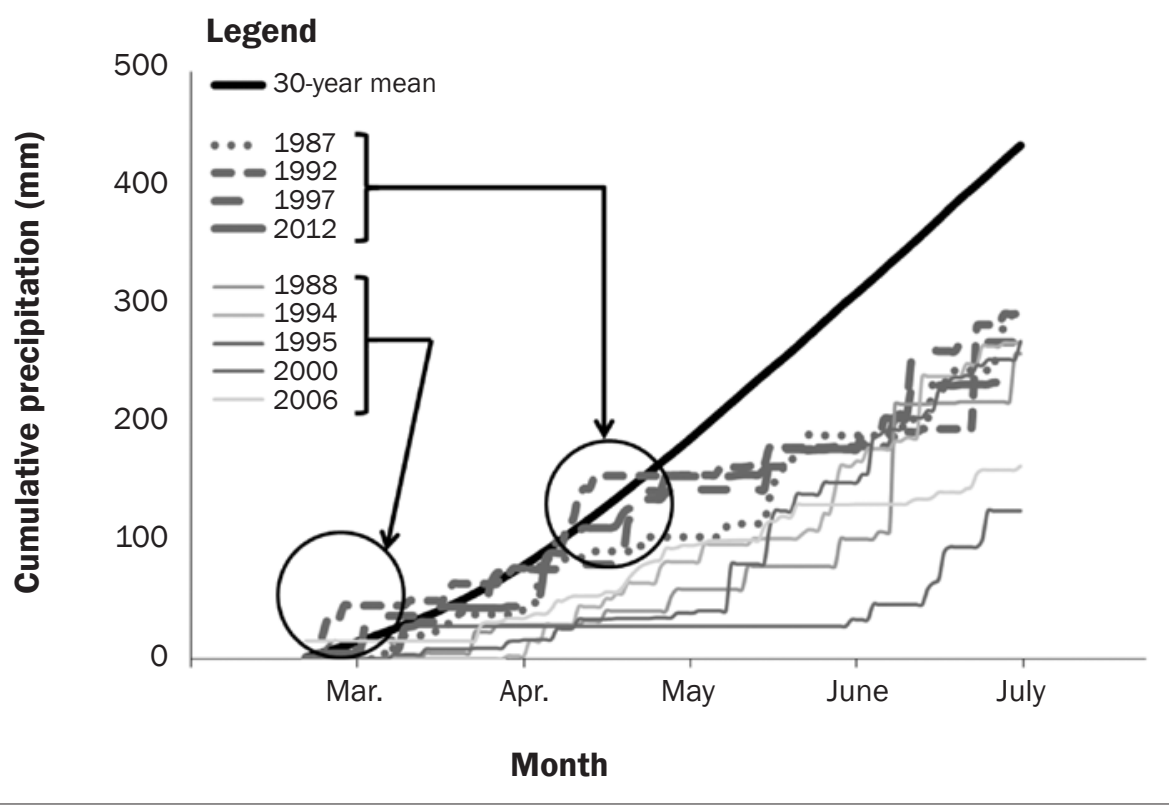

to germination occurring at a later date (i.e., after snowmelt in the following spring months) than that observed for ISUAG and to the relatively cooler air temperatures than that observed for SEPAC (figure 2). The average above ground living biomass at time of rye termination varied substantially among the Iowa and Indiana sites (table 4). Krueger et al. (2011) reported that soil moisture after termination of rye cover crop did not differ from their control plots when rye production was less than $900 \mathrm{~kg} \mathrm{ha}^{-1}\left(804 \mathrm{lb} \mathrm{ac}^{-1}\right)$ in Minnesota. Similarly, Clark et al. (1997a, 1997b) also reported that soil moisture after termination of rye cover crop did not differ from their control plots for rye biomass production up to $2,919 \mathrm{~kg} \mathrm{ha}^{-1}\left(2,607 \mathrm{lb} \mathrm{ac}^{-1}\right)$ in the Piedmont of Maryland during the severe drought of 1991. However, Clark et al. (1997a, 1997b) also reported that soil moisture was significantly greater during 15 of the 27 weekly measurements made when rye biomass production was 3,935 and $2,330 \mathrm{~kg}$ $\mathrm{ha}^{-1}\left(3,514\right.$ and $\left.2,081 \mathrm{lb} \mathrm{ac}^{-1}\right)$ in the Coastal Plains of Maryland during 1990 and 1991, in which precipitation was relatively similar to the 20 -year mean precipitation. Therefore, even though rye planted before soybeans yielded about twice as much aboveground living biomass than rye planted before corn, due to the longer growing period, no significant differences were observed in soil $\theta$ or SWS at ADW (table 2 and 4).

In contrast to ADW, rye cover crop at ISUAG had significantly greater soil $\theta$ at the $10 \mathrm{~cm}$ soil depth and SWS to $80 \mathrm{~cm}(31.5$ in) depth by $0.029 \mathrm{~cm}^{3} \mathrm{~cm}^{-3}\left(0.029 \mathrm{in}^{3} \mathrm{in}^{-3}\right)$ and $1.9 \mathrm{~cm}$ (0.75 in), respectively, than when no rye cover crop was grown when averaged across corn and soybean crops during period 1 ( $p$-value $\leq 0.03$; table 2 ). Additionally, soil $\theta$ in depth 1 and SWS were significantly and oppositely affected by crop during period 1 at ISUAG ( $p$-value $\leq 0.03$; table 2$)$. Soil $\theta$ in depth 1 was $0.027 \mathrm{~cm}^{3} \mathrm{~cm}^{-3}\left(0.027 \mathrm{in}^{3} \mathrm{in}^{-3}\right)$ greater for Cs than that for $\mathrm{cS}$, whereas, SWS was $2.5 \mathrm{~cm}$ (1 in) greater for $\mathrm{cS}$ than that for Cs (table 2). Although no significant crop by rye interaction effect was observed for depth 1 in period 1 at ISUAG ( $p$-value $=0.14)$, differences in soil $\theta$ were $0.051 \mathrm{~cm}^{3} \mathrm{~cm}^{-3}$ $\left(0.051 \mathrm{in}^{3} \mathrm{in}^{-3}\right)$ for $\mathrm{rS}$ and S compared to only $0.004 \mathrm{~cm}^{3} \mathrm{~cm}^{-3}\left(0.004 \mathrm{in}^{3} \mathrm{in}^{-3}\right)$ for $\mathrm{rC}$ and Cs. During period 2 at ISUAG, the rye cover crop had significantly greater soil $\theta$ by 0.041 and $0.033 \mathrm{~cm}^{3} \mathrm{~cm}^{-3}\left(0.041\right.$ and $\left.0.033 \mathrm{in}^{3} \mathrm{in}^{-3}\right)$ at the 10 and $20 \mathrm{~cm}$ (3.9 to $7.9 \mathrm{in}$ ) soil depths and significantly greater SWS to $80 \mathrm{~cm}(31.5$ in) depth by $2.7 \mathrm{~cm}$ (1.1 in) than when no rye cover crop was grown (table 2). Similar to that during period 1 , SWS to $80 \mathrm{~cm}(31.5$ in) was also significantly greater ( $p$-value $=$ $0.09)$ by $3.3 \mathrm{~cm}(1.3 \mathrm{in})$ for $\mathrm{cS}$ than that for Cs, though no crop by cover crop interaction was observed (table 2). The greater SWS to $80 \mathrm{~cm}$ (31.5 in) depth for soil planted to cS than that for Cs in 2012 is likely due to the residues left from the previous year's crop (i.e., soil covered with corn residue for $\mathrm{cS}$ and soil covered with soybean residue for Cs in spring of 2012). Corn has been reported to leave greater quantities of mass and aerial coverage of residues on the soil surface than that of soybean (Dickey et al. 1985). Similar to that of rye biomass, the greater quantities of the cash crop residue would be expected to increase the mulching effect, reduce soil evaporation and conserve water in the soil profile (Mulumba and Lal 2008; Baumhardt and Jones 2002; Clark et al. 1997b). Similarly to depth 1 of period 1 , differences in soil $\theta$, for depth 1 of period 2 at ISUAG, were $0.072 \mathrm{~cm}^{3} \mathrm{~cm}^{-3}\left(0.072 \mathrm{in}^{3} \mathrm{in}^{-3}\right)$ for $\mathrm{rS}$ and $\mathrm{cS}$ compared to only $0.013 \mathrm{~cm}^{3} \mathrm{~cm}^{-3}\left(0.013 \mathrm{in}^{3}\right.$ $\left.\mathrm{in}^{-3}\right)$ for $\mathrm{rC}$ and Cs. These main effects and interactions are apparent when viewing soil $\theta$ and SWS over time during the two time periods at ISUAG (figure 4). For example, at ISUAG, soil $\theta$ at the $10 \mathrm{~cm}$ soil depth was consistently greater in $\mathrm{rS}$ than $\mathrm{cS}$ during both period 1 and 2 with exception of early May in period 1 when the rye cover crop was likely rapidly growing and transpiring during a relatively longer period (i.e., 13 days) between precipitations $\geq 1 \mathrm{~cm}$ ( 0.4 in), thus lowering soil $\theta$ (figure 4). Following precipitation events on March 18 through March 21, the difference in soil $\theta$ is greatest between $\mathrm{rS}$ and $\mathrm{cS}$ (figure 4). These differences in soil $\theta$ diminished over the following seven days to nearly zero-likely due to the transpiring rye cover crop. However, the next precipitation events on March 30 and 31 , restored differences in soil $\theta$ between $\mathrm{rS}$ and $\mathrm{cS}$ to values similar to those observed on March 18 (figure 4). This may be due to the rye cover crop reducing the quantity of precipitation going to runoff and increasing the quantity of water infiltrated into the soil (Steele et al. 2012). However, soil $\theta$ in depth 1 of $\mathrm{rS}$ decreased below that of $\mathrm{cS}$ between April 4 and April 13 when precipitation was minimal for 13 consecutive days-again likely due to the transpiring rye cover crop-until the next precipitation event (figure 4). These differences in soil moisture among cover crop treatments over time prior to and after precipitations events demonstrate the apparent impact 


\section{Figure 4}

Examples of volumetric soil water content at the $10 \mathrm{~cm}$ depth and soil water storage to $80 \mathrm{~cm}$ depth in corn and soybeans with and without winter rye cover crop for 2012 at lowa State University Agronomy and Agricultural Engineering Research Farm (ISUAG). Period 1 represents the time period prior to planting of the cash crop, and period 2 represents time after rye termination and emergence of the cash crop.

(a)

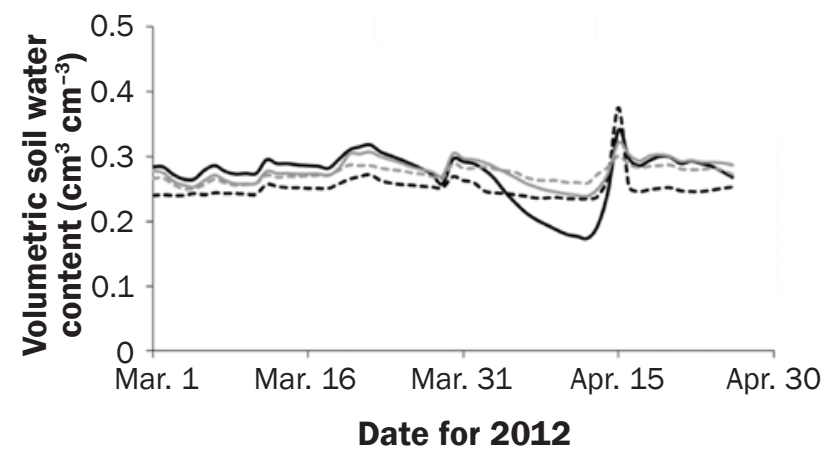

(c)

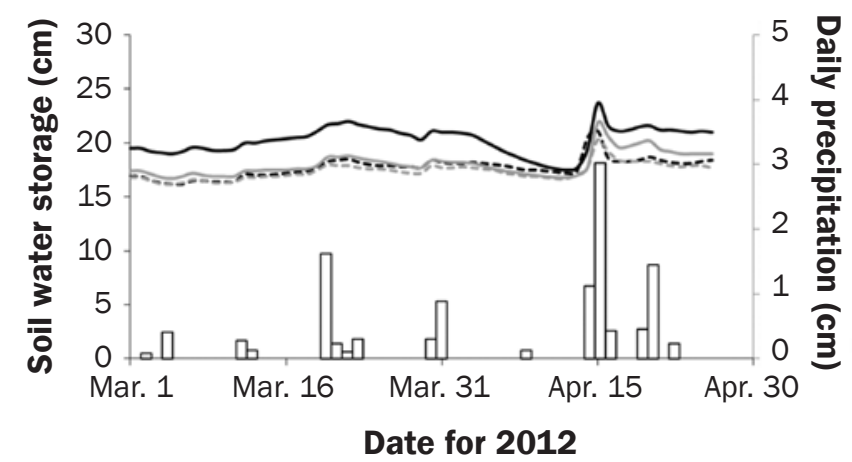

(b)

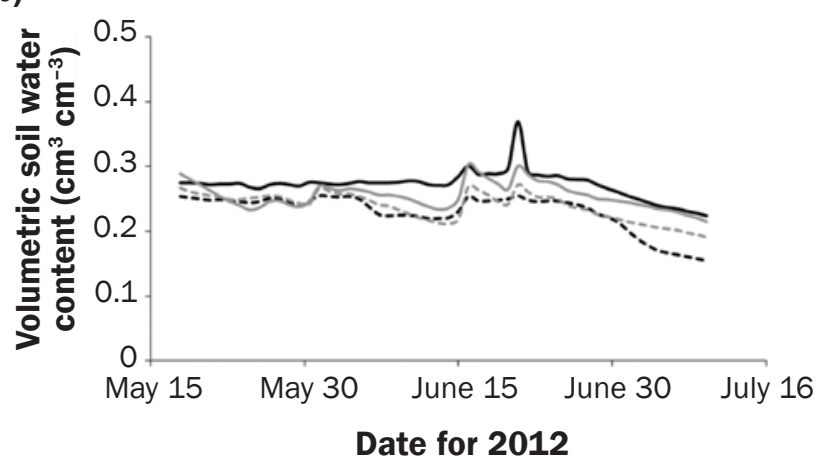

(d)

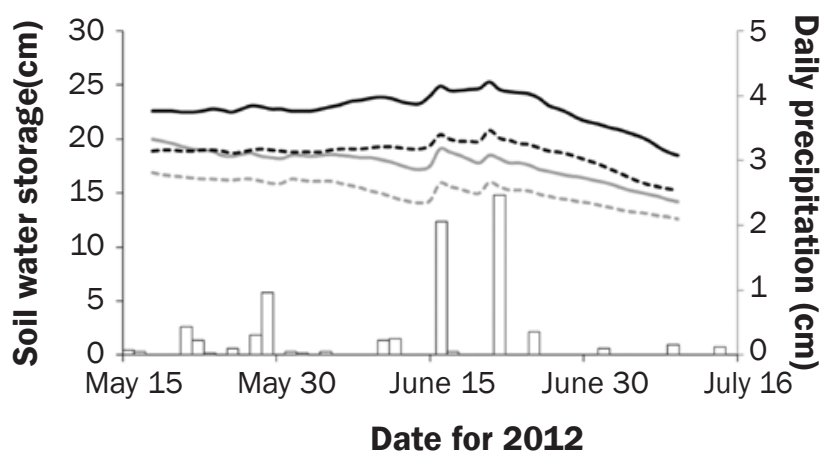

of individual precipitation events that are capable of recharging soil moisture, and eliminating any effect of soil-moisture history on the effectiveness of a soil mulch to conserve soil water. Once the rye cover crop was terminated, the process of transpiration from the cover crop was eliminated from the effects observed during period 2. In contrast with observed differences in soil $\theta$ and SWS in period 1, the soil $\theta$ and SWS differences between $\mathrm{rS}$ and $\mathrm{cS}$ in period 2 did not appear to be affected by the duration between precipitation events, and are directly attributed to the mulching effect from the now dead rye cover crop (figure 4). These trends and the differences in soil $\theta$ were similar for $\mathrm{rC}$ and $\mathrm{Cs}$ but at a lesser degree than that with $\mathrm{rS}$ and $\mathrm{cS}$ with the exception of SWS during period 2 when differences between $\mathrm{rC}$ and $\mathrm{Cs}$ were similar to those between $\mathrm{rS}$ and $\mathrm{cS}$ (figure 4). This is likely due to $\mathrm{rS}$ having over twice as much biomass production than $\mathrm{rC}$, and there- fore having a stronger mulch effect (table 4). Additionally, even though soil $\theta$ of $\mathrm{rS}$ and $\mathrm{rC}$ dropped below that of $\mathrm{cS}$ and Cs, respectively, for the $10 \mathrm{~cm}$ (3.9 in) soil depth during period 1 , no significant differences were observed in the SWS to $80 \mathrm{~cm}$ (31.5 in) depth (figure 4).

At SEPAC, soil $\theta$ was different between with and without rye cover crop even before initiation of the first planting of the rye cover crop (table 3; figure 5). These differences persisted into the following observation periods (table 3; figure 5). However, the degree of differences did not increase but instead somewhat decreased during the later periods in comparison to period -2 (table 3; figure 5). Therefore, even though significant differences in soil $\theta$ were observed between crops with and without a winter rye cover crop during the periods following rye cover crop planting, these differences were likely associated with the preexisting site conditions and not due to the rye cover crop. These results imply that the rye cover crop did not have an impact on soil moisture at SEPAC even though the greatest quantity of rye grass production was observed here compared to the Iowa sites. However, SEPAC had an average of 588 and $664 \mathrm{~kg}$ $\mathrm{ha}^{-1}$ (525 and $593 \mathrm{lb} \mathrm{ac}^{-1}$ ) of weed growth in the $\mathrm{Cs}$ and cS treatments, respectively, whereas no measureable quantities of weeds were observed at ADW or ISUAG.

With respect to differences in total above ground living biomass (i.e., rye plus weeds), SEPAC falls between that of the amount at the ADW and ISUAG sites (table 4). The results indicate that if differences in total above ground living biomass are relatively low (i.e., ADW), then no significant differences in soil $\theta$ and SWS will be observed for cornsoybean rotations with or without the use of a winter rye cover crop during drought conditions (table 2 and 4). In contrast, if substantial 
Table 2

Repeated measures autoregressive moving average (ARMA [1,1]) analysis of variance summary of soil water content $\left(\mathrm{cm}^{3} \mathrm{~cm}^{-3}\right)$ and storage $(\mathrm{cm})$ under corn-soybean rotation with and without winter rye cover crop at the Agricultural Drainage Research Site (ADW), lowa State University Agronomy and Agricultural Engineering Farm (ISUAG) sites in 2012.

\begin{tabular}{|c|c|c|c|c|c|c|c|c|c|c|c|c|}
\hline \multirow[b]{4}{*}{ Source } & \multicolumn{6}{|l|}{ ADW } & \multicolumn{6}{|l|}{ ISUAG } \\
\hline & \multicolumn{3}{|l|}{ Period 1} & \multicolumn{3}{|l|}{ Period 2} & \multicolumn{3}{|l|}{ Period 1} & \multicolumn{3}{|l|}{ Period 2} \\
\hline & D1 & D2 & sws & D1 & D2 & sws & D1 & D2 & sws & D1 & D2 & sWs \\
\hline & \multicolumn{12}{|l|}{$p$-values } \\
\hline Block & 0.03 & 0.76 & 0.07 & $<0.01$ & 0.35 & 0.03 & 0.75 & 0.13 & 0.25 & 0.58 & 0.40 & 0.89 \\
\hline Date & $<0.001$ & $<0.001$ & $<0.001$ & $<0.001$ & $<0.001$ & $<0.001$ & $<0.001$ & $<0.001$ & $<0.001$ & $<0.001$ & $<0.001$ & $<0.001$ \\
\hline Crop & 0.16 & 0.52 & 0.18 & 0.31 & 0.19 & 0.17 & 0.03 & 0.31 & 0.01 & 0.35 & 0.11 & 0.09 \\
\hline Rye & 0.99 & 0.26 & - & 0.32 & 0.31 & - & 0.02 & 0.14 & 0.03 & $<0.01$ & 0.05 & 0.09 \\
\hline Crop*rye & 0.95 & 0.15 & - & $<0.01$ & 0.17 & - & 0.14 & 0.13 & 0.66 & 0.04 & 0.14 & 0.42 \\
\hline Source & \multicolumn{12}{|c|}{ Contributed variance (\%) } \\
\hline Block & 1.7 & $<0.1$ & 3.4 & 1.1 & 0.2 & 4.3 & $<0.1$ & 0.5 & 0.1 & 0.1 & 0.1 & $<0.1$ \\
\hline Date & 97.8 & 99.6 & 94.4 & 97.2 & 98.5 & 94.9 & 97.0 & 98.4 & 97.8 & 95.6 & 98.1 & 95.9 \\
\hline Crop & 0.4 & $<0.1$ & 0.1 & 0.1 & 0.5 & 0.9 & 1.2 & 0.2 & 1.3 & 0.2 & 0.5 & 2.1 \\
\hline Rye & $<0.1$ & 0.1 & - & 0.1 & 0.2 & - & 1.4 & 0.5 & 0.8 & 3.1 & 0.9 & 2.1 \\
\hline Crop*rye & $<0.1$ & 0.3 & - & 1.5 & 0.5 & - & 0.5 & 0.5 & $<0.1$ & 1.1 & 0.4 & 0.2 \\
\hline 2012 Crop & Means & & & & & & & & & & & \\
\hline Corn & 0.245 & 0.277 & - & 0.252 & 0.279 & - & $0.269 a$ & 0.284 & $17.40 \mathrm{~b}$ & 0.252 & 0.266 & $16.80 \mathrm{~b}$ \\
\hline Soybean & 0.261 & 0.289 & 17.70 & 0.260 & 0.317 & 19.40 & $0.242 b$ & 0.300 & $19.90 a$ & 0.242 & 0.301 & $20.10 a$ \\
\hline Rye & Means & & & & & & & & & & & \\
\hline Yes & 0.253 & 0.272 & 18.10 & 0.252 & 0.284 & 19.70 & $0.270 a$ & 0.300 & $19.60 a$ & $0.267 a$ & $0.300 a$ & $19.8 a$ \\
\hline No & 0.253 & 0.293 & 17.40 & 0.260 & 0.312 & 19.0 & $0.241 b$ & 0.280 & $17.70 b$ & $0.226 b$ & $0.267 b$ & $17.1 b$ \\
\hline
\end{tabular}

*Indicates test of interaction.

Notes: Period 1 = March 1, 2012 to planting of cash crop (corn planted on April 26 and May 10 at ISUAG and ADW, respectively; soybeans planted on May 11 and 16 at ISUAG and ADW, respectively). Period $2=$ cash crop emergence (i.e., approximately one week after planting) to July 10, 2012. D1 = $10 \mathrm{~cm}$ depth. D2 $=20 \mathrm{~cm}$ depth. SWS = soil water storage to $80 \mathrm{~cm}$ depth. Different letters indicate significant differences at the 0.05 level.

differences in total above ground living biomass exist (i.e., ISUAG) among corn-soybean rotation with and without winter rye cover crop, then significant increases in soil $\theta$ and SWS can be observed as long as periodic rains occur when the rye cover crop is actively transpiring (table 2 and 4). This is particularly the case after termination of the rye when the mulch effect is potentially greatest. Therefore, the impacts of rye cover crop on soil moisture may be dependent on rye biomass growth, but neither small nor large rye cover crops appeared to diminish soil moisture and soil water storage even in a year with drier than normal conditions. Due to the apparent impact of individual precipitation events that are capable of recharging soil to a high soil moisture status, these trends in soil moisture among rye cover crop treatments are expected to be representative of years with spring, early summer, or annual drought conditions, regardless of whether or not consecutive annual droughts have occurred. Additionally, though only two soil textural classes (i.e., clay loam and silt loam) were used in this study, the suborder classification of these soils (i.e., Udoll,Aquoll, and Udalf) dominate the glacial till landscapes of the Midwest, from western Kansas to Ohio, and may be found in various landforms throughout the East Coast and southern United States (USDA NRCS 2013a, 2013b). Clark et al. (1997a,1997b) also reported similar trends in soil moisture among rye cover crop treatments on a silt loam Udult soil, in which similar soils dominate the residual and coastal plain soils of the southeastern United States (USDA NRCS 2013c). Winter rye cover crop biomass production, important for soil water conservation benefits, is well adaptable to a wide range of climate and soil types across all of the United States and Canada (USDA NRCS 2013d). Thus, these trends in soil moisture among rye cover crop treatments are also expected to be generally representative across a broader range of soils and landforms than those used in this study, though the magnitude of soil water conservation due to a rye cover crop may vary.

\section{Summary and Conclusions}

In conclusion, soil water during the drought of 2012 was affected by rye cover crops at the ISUAG site in Iowa, but was not affected by rye cover crops at the ADW site in Iowa and the SEPAC site in Indiana. Soil water conservation at the ISUAG site was greatest following termination of the rye cover crop and when rye biomass production was greatest. During this time period, soil $\theta$ was on average 0.041 and $0.033 \mathrm{~cm}^{3} \mathrm{~cm}^{-3}\left(0.041\right.$ and $\left.0.033 \mathrm{in}^{3} \mathrm{in}^{-3}\right)$ greater at the 10 and $20 \mathrm{~cm}$ (3.9 and $7.9 \mathrm{in}$ ) depths, respectively, in crops with a rye cover crop than without a rye cover crop. Similarly, soil water at ISUAG during an actively growing rye cover crop was significantly greater at the $10 \mathrm{~cm}$ (3.9 in) depth and numerically greater at the $20 \mathrm{~cm}$ (7.9 in) depth in crops with a rye cover crop than those without a rye cover crop. Thus, the incorporation of a rye cover crop into a corn-soybean rotation during a drought as the 2012 drought did not have a detrimental impact of lowering soil water conditions. Instead, a rye cover crop had either no impact on soil water conservation when 
Table 3

Repeated measures autoregressive moving average (ARMA [1,1]) analysis of variance summary of soil water content $\left(\mathrm{cm}^{3} \mathrm{~cm}^{-3}\right)$ and storage $\left(\mathrm{cm}^{-}\right)$ under corn-soybean rotation with and without winter rye cover crop at Southeast Purdue Agricultural Center (SEPAC) site in 2012.

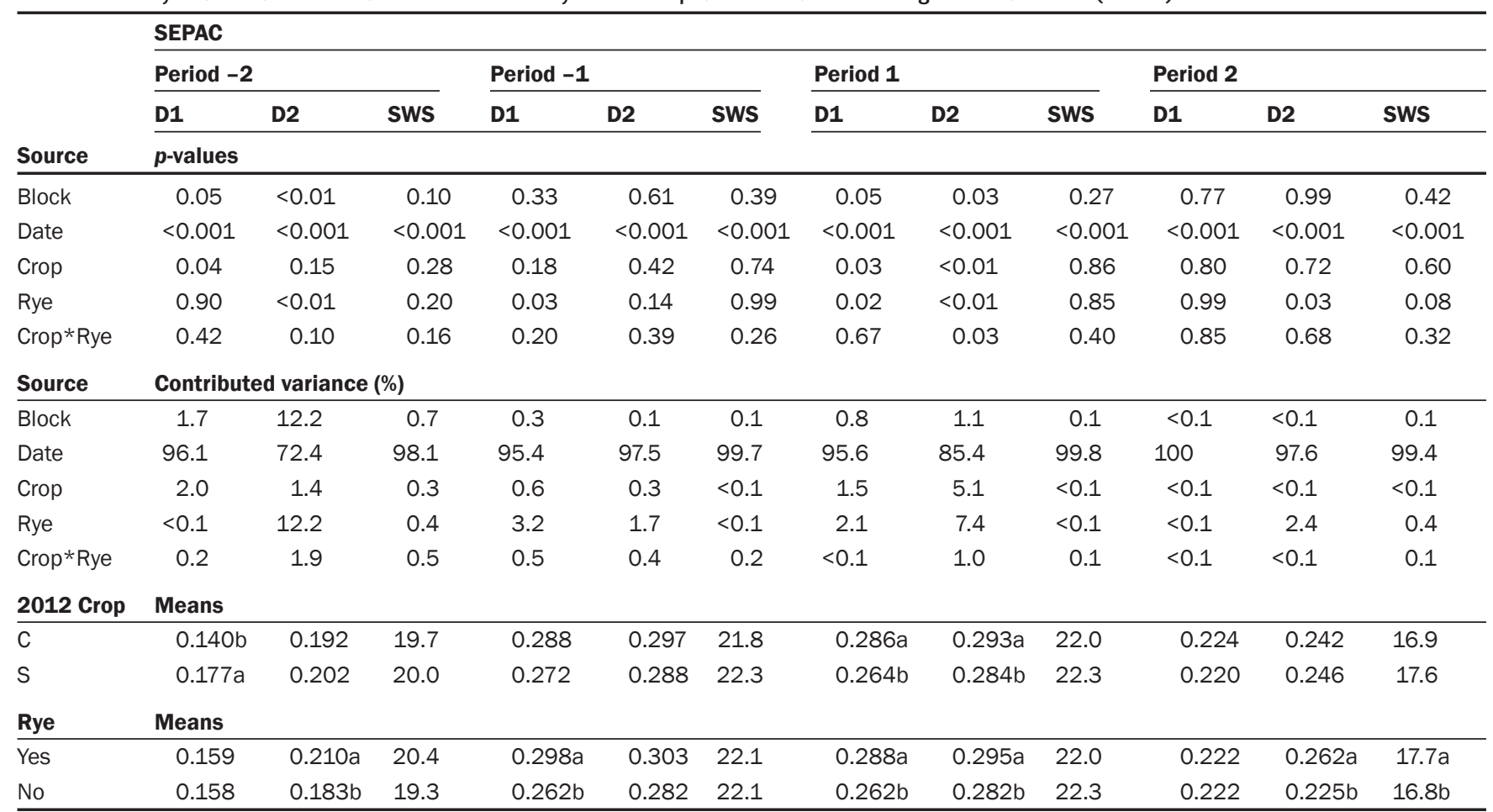

*Indicates test of interaction.

Notes: Period $-2=$ prior to planting of rye from July 14, to August 20, in 2011. Period $-1=$ rye was dormant from January 1 , to February 12 , in 2012. Period 1 = March 1, to the planting of the cash crop on April 24, 2012. Period $2=$ emergence of cash crop (i.e., approximately one week after planting) to July 20 in 2012. D1 $=10 \mathrm{~cm}$ depth. D2 $=20 \mathrm{~cm}$ depth. SWS = soil water storage to $80 \mathrm{~cm}$ depth. Different letters indicate significant differences at the 0.05 level.

\section{Table 4}

Mean aboveground biomass production prior to planting of cash crops in 2012 at the Agricultural Drainage Research Site (ADW), lowa State University Agronomy and Agricultural Engineering Farm (ISUAG), and Southeast Purdue Agricultural Center (SEPAC) sites. Standard deviations are in parentheses.

\begin{tabular}{|c|c|c|c|}
\hline \multirow[b]{2}{*}{ Treatment } & \multicolumn{3}{|c|}{ Above ground biomass } \\
\hline & ADW $\left(\mathrm{kg} \mathrm{ha}^{-1}\right)$ & ISUAG (kg ha-1) & SEPAC $\left(\mathrm{kg} \mathrm{ha}^{-1}\right)$ \\
\hline $\mathrm{rC}$ & $136(53)$ & 1,039 (131) & 1,384 (304) \\
\hline Cs & $0(-)$ & $0(-)$ & $612(40)$ \\
\hline rS & $322(145)$ & $2,207(101)$ & $1,371(54)$ \\
\hline cS & $0(-)$ & $0(-)$ & 598 (31) \\
\hline
\end{tabular}

Notes: $\mathrm{rC}=$ corn following rye. $\mathrm{Cs}=$ corn without $r y e . \mathrm{rS}=$ soybean following rye. $\mathrm{cS}=$ soybean without rye.

rye biomass production was relatively low or significantly increased soil water conservation during the period when cash crops are most sensitive to water-limited stresses.

\section{Acknowledgements}

This research was funded by the USDA National Institute of Food and Agriculture (NIFA) Cropping Systems Coordinated Agricultural Project Climate Change,
Baumhardt, R.L., and O.R. Jones. 2002. Residue management and tillage effects on soil-water storage and grain yield of dryland wheat and sorghum for a clay loam in Texas. Soil and Tillage Research 68:71-82.

Cambell, R.B., D.L. Karlen, and R.E. Sojka. 1984. Conservation tillage for maize production in the U.S. Southeastern Coastal Plain. Soil \& Tillage Research 4:511-529.

Clark, A.J., A.M. Decker, J.J. Meisinger, and M.S. McIntosh. 1997a. Kill date of vetch, rye, and vetch-rye mixture: I. Cover crop and corn nitrogen. Agronomy Journal 89:427-434.

Clark, A.J., A.M. Decker, J.J. Meisinger, and M.S. McIntosh. 1997b. Kill date of vetch, rye, and vetch-rye mixture: II. Soil moisture and corn yield. Agronomy Journal 89:434-441.

Daigh, A.L., X. Zhou, M.J. Helmers, C.H. Pederson, R. Ewing, and R. Horton. 2014. Subsurface drainage flow and soil water dyanmics of reconstructed prairies and corn rotations for biofuel production. Vadose Zone Journal doi:10.2136/vzj2013.10.0177.

\section{References}

Ball-Coelho, B.R., R.C. Roy, and A.J. Bruin. 2005. Longterm effects of late-summer overseeding of winter rye on corn grain yield and nitrogen balance. Plant Science $85: 543-554$.
Dapaah, H.K., and T.J.Vyn. 1998. Nitrogen fertilization and cover crop effects on soil structural stability and corn performance. Communications in Soil Science and Plant Analysis 29:2557-2569. 


\section{Figure 5}

Examples of volumetric soil water content at the $10 \mathrm{~cm}$ depth of 2012 corn production crop with and without winter rye cover crop for all periods during 2011 through 2012 at Southeast Purdue Agricultural Center (SEPAC). Period -2 was prior to planting of rye from July 14 to August 20 in 2011, period -1 was when rye was dormant from January 1 to February 12 in 2012, period 1 represents the time period prior to planting of the cash crop, and period 2 represents time after rye termination and emergence of the cash crop.

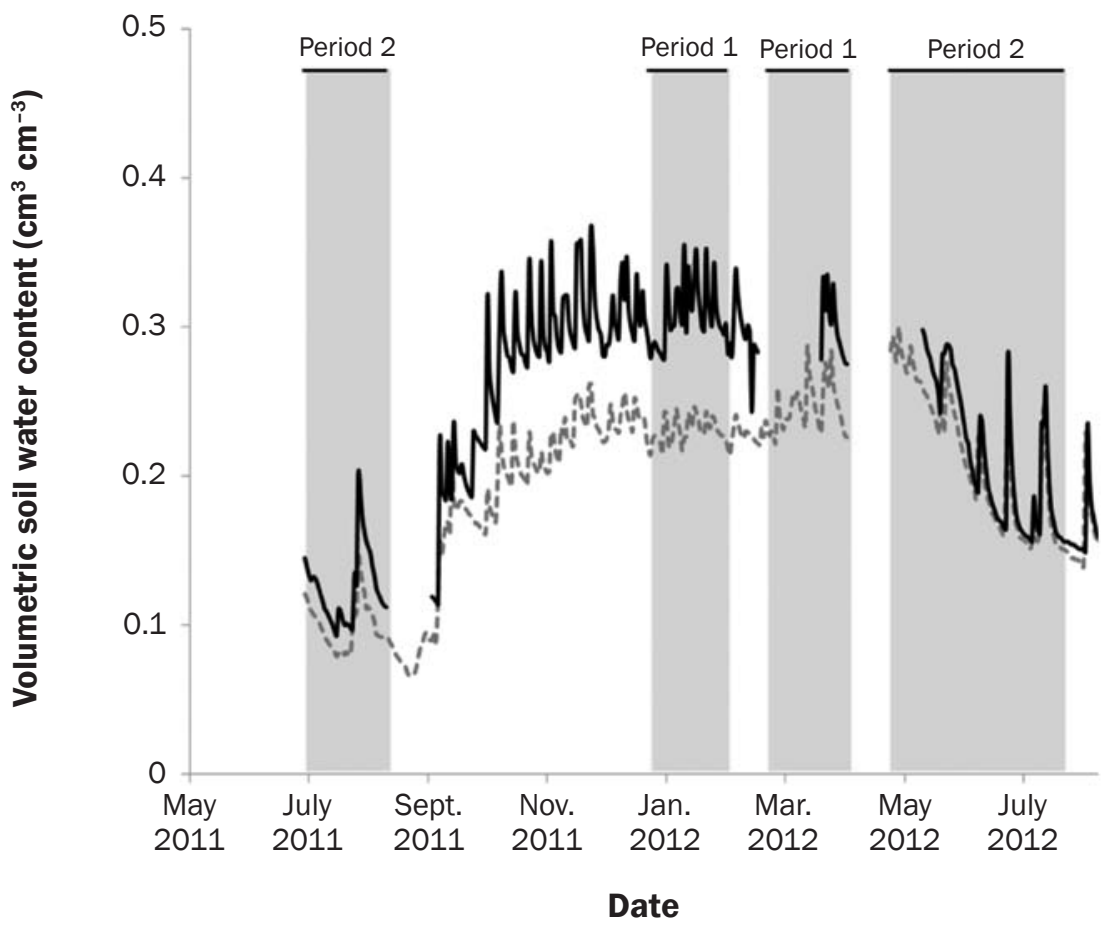

\section{Legend}

---- No cover — Rye

Denmead, O.T., and R.H. Shaw. 1960. The effects of soil moisture stress at different stages of growth on the development and yield of corn. Agronomy Journal 52:272-274

Dickey, E.C., D.P. Shelter, P.J. Jasa, and T.R. Peterson. 1985 Soil erosion from tillage systems used in soybean and corn residues. Transactions of the American Society of Agricultural Engineers 28:1124-1140.

Easterling, D.R., and T.R. Karl. 2001. Potential consequences of climate variability and change for the Midwestern United States. Report Prepared for the US Global Change Research Program, 167-188. Cambridge, UK: Cambridge University Press.

Ewing, R.P., M.G. Wagger, and H.P. Denton. 1991. Tillage and cover crop management effects on soil water and corn yield. Soil Science Society of America Journal 55:1081-1085

French, R.J., and J.E. Schultz. 1984. Water use efficiency of wheat in a Mediterranean-type environment. I The relation between yield, water use and climate. Australian Journal of Agricultural Research 35:743-764.
Fulton, J.M. 1970. Relationships among soil moisture stress, plant populations, row spacing and yield of corn. Canadian Journal of Plant Science 50:31-38.

Gilbert, N. 2012. Drought devastates US crops. Nature News. doi:10.1038/nature.2012.11065

Hansen, E.M., J. Djurhuus, and K. Kristensen. 2000. Nitrate leaching as affected by introduction or discontinuation of cover crop use. Journal of Environmental Quality 29:1110-1116

Hatfield, J.L. 2011. Soil management for increasing water use efficiency in field crops under changing climates. In Soil Management: Building a Stable Base for Agriculture, eds. J.L.Hatfield and T.J. Sauer. Madison,WI:American Society of Agronomy and Soil Science Society of America.

Hatfield, J.L., T.J. Sauer, and J.H. Prueger. 2001. Managing soils for greater water use efficiency:A review.Agronomy Journal 93:271-280.

Horton, R. 1989. Canopy shading effects on soil heat and water flow. Soil Science Society of America Journal 53:669-679.

Horton, R., K.L. Bristow, G.J. Kluitenberg, and T.J. Sauer. 1996. Crop residue effects on surface radiation and energy balance - Review. Theoretical and Applied Climatology 54:27-37.

Irmak, S., D.Z. Haman, and R. Bastug. 2000. Determination of crop water stress index for irrigation timing and yield estimation of corn. Agronomy Journal 92:1221-1227.

Inderjit, and K.I. Keating. 1999. Allelopathy: Principles, procedures, processes, and promises for biological control. Advances in Agronomy 67:141-231.

Johnson, T.J., T.C. Kaspar, K.A. Kohler, S.J. Corak, and S.D. Logsdon. 1998. Oat and rye overseeded into soybean as fall cover crop in the upper Midwest. Journal of Soil and Water Conservation 53:276-279.

Kaspar,T.C., and J.W. Singer. 2011. The use of cover crops to manage soil. In Soil Management: Building a Stable Base for Agriculture, eds. J.L. Hatfield and T.J. Sauer. Madison, WI: American Society of Agronomy and Soil Science Society of America.

Kaspar, T.C., J.K. Radke, and J.M. Laflen. 2001. Small grain cover crops and wheel traffic effects on infiltration, runoff, and erosion. Journal of Soil and Water Conservation 56:160-164.

Kladivko, E.J., J.R. Frankenberger, D.B. Jaynes, D.W. Meek, B.J. Jenkinson, and N.R. Fausey. 2004. Nitrate leaching to subsurface drains as affected by drain spacing and changes in crop production system. Journal of Environmental Quality 33:1803-1813.

Krueger, E.S., T.E. Ochsner, P.M. Porter, and J.M Baker. 2011. Winter rye cover crop management influences on soil water, soil nitrate, and corn development. Agronomy Journal 103:316-323.

Lawlor, P.A., M.J. Helmers, J.L. Baker, S.W. Melvin, and D.W. Lemke. 2008. Nitrogen application rate effect on nitrate-nitrogen concentration and loss in subsurface drainage for a corn-soybean rotation. Transactions of the American Society of Agricultural Biological Engineers 51:83-94.

McMaster, G.S., R.M. Aiken, and D.C. Nielsen. 2000. Optimizing wheat harvest cutting height for harvest efficiency and soil and water conservation. Agronomy Journal 92:1104-1108.

Miguez, I.C., and G.A. Bollero. 2006. Winter cover crops in Illinois: Evaluation of ecophysiological characteristics of corn. Crop Science 46:1536-1545.

Moschler, W.W., G.M. Shear, D.L. Hallok, R.D. Sears, and G.D. Jones. 1967. Winter cover crops for sod-planted corn: Their selection and management. Agronomy Journal 59:547-551.

Mulumba, L.N., and R. Lal. 2008. Mulching effects on selected soil physical properties. Soil and Tillage Research 98:106-111.

NOAA (National Oceanic and Atmospheric Administration). 2013a. NOWData. NOAA Online Weather Data. Ames, IA: National Oceanic Atmospheric Administration. http://www.nws.noaa. gov/climate $/ \mathrm{xmacis}$.php? $\mathrm{wfo}=\mathrm{dmx}$. 
NOAA NCDC (National Oceanic and Atmospheric Administration National Climatic Data Center). 2013. Station history and data inventory: North Vernon 2 ESE. http:// www.ncdc.noaa.gov/cdo-web/datasets/NORMAL_DLY/ stations/GHCND:USC00126435/detail.

NOAA-NCDC. 2012. Drought - July 2012. http://www. ncdc.noaa.gov/sotc/drought/2012/7.

Or, D., J.M. Wraith, D.A. Robinson, and S.B. Jones. 2012 Soil water content and water potential relationships. In Handbook of Soil Sciences: Properties and Processes, eds. P.M. Huang, Y. Li, and M.E. Sumner. Boca Raton, FL: CRC Press, Taylor \& Francis Group.

Patrick, W.H., Jr., C.B. Haddon, and J.A. Hendrix. 1957. The effect of longtime use of winter cover crops on certain physical properties of Commerce loam. Soil Science Society of America Journal 21:366-368.

Qi, Z., and M.J. Helmers. 2010. Soil water dynamics under winter rye cover crop in central Iowa. Vadose Zone Journal 9:53-60.

Raimbault, B.A., T.J. Vyn, and M. Tollenaar. 1990. Corn response to rye cover crop management and spring tillage systems. Agronomy Journal 82:1088-1093.

Reeleder, R.D., J.J. Miller, B.R.B. Coelho, and R.C. Roy. 2006. Impacts of tillage, cover crop, and nitrogen on populations of earthworms, microarthropods, and soil fungi in a cultivated fragile soil. Applied Soil Ecology 33:243-257.

Sadras, V.O., and J.F. Angus. 2006. Benchmarking wateruse-efficiency of rainfed wheat in dry environments. Australian Journal of Agricultural Research 57:847-856.

Sauer, T.J., J.L. Hatfield, and J.L. Prueger. 1996a. Corn residue age and placement effects on evaporation and soil thermal regime. Soil Science Society of America Journal 60:1558-1564.

Sauer, T.J., J.L. Hatfield, and J.L. Prueger. 1996b. Aerodynamic characteristics of standing corn stubble. Agronomy Journal 88:733-739.

Schiermeier, Q. 2013. Climate models fail to 'predict' US droughts. Nature 496:284.

Seneviratne, S.I. 2012. Historical drought trends revisited. Nature 491:338-339.

Steele, M.K., FJ. Coale, and R.L. Hill. 2012. Winter annual cover crop impacts on no-till soil physical properties and organic matter. Soil Science Society of America Journal 76:2164-2173.

Strock, J.S., P.M. Porter, and M.P. Russelle. 2004. Cover cropping to reduce nitrate loss through subsurface drainage in the northern U.S. Corn Belt. Journal of Environmental Quality 33:1010-1016.

Unger, P.W., and M.R. Vigil. 1998. Cover crop effects on soil water relationships. Journal of Soil and Water Conservation 53:200-207.

USDA NRCS (Natural Resources Conservation Service). 2013a. Mollisols Map. http://www.nrcs. usda.gov/wps/portal/nrcs/detail/soils/survey/ class/?cid=nrcs142p2_053604.
USDA NRCS. 2013b. Alfisols Map. http://www.nrcs. usda.gov/wps/portal/nrcs/detail/soils/survey/ class/?cid=nrcs142p2_053591.

USDA NRCS. 2013c. Ultisols Map. http://www.nrcs. usda.gov/wps/portal/nrcs/detail/soils/survey/ class/?cid=nrcs142p2_053610.

USDA-NRCS. 2013d. PLANTS Database: Cereal Rye Plant Guide. http://plants.usda.gov/plantguide/pdf/pg_sece.pdf.

Wagger, M.G., and D.B. Mengel. 1988. The role of nonleguminous cover crops in the efficient use of water and nitrogen. In Cropping Strategies for Efficient Use of Water and Nitrogen, ed. W.L. Hargrove. Madison, WI: Agronomy Society of America, Crop Science Society of America, and Soil Science Society of America.

Wander, M.M., S.J. Traina, B.R. Stinner, and S.E. Peters 1994. Organic and conventional management effects on biologically active soil organic matter pools. Soil Science Society of America Journal 58:1130-1139. 